\title{
Emotional intelligence as an aspect in the performance of the work of a global manager
}

\author{
Branislav Mičieta ${ }^{1}$, Vladimíra Biňasová ${ }^{1, *}$, Beáta Furmannová1, Gabriela Gabajová $^{1}$, and \\ Marta Kasajová ${ }^{1}$ \\ ${ }^{1}$ University of Zilina, Faculty of Mechanical Engineering, Department of Industrial Engineering, \\ Univerzitna 1, 01026 Zilina, Slovakia
}

\begin{abstract}
Research background: Emotional intelligence is a set of emotional and social abilities and skills of a manager. Nowadays, the environment is global and very complex, and the association between emotional intelligence and performance in enterprises remains an important area of worry for managers and employees' globally. The article focuses on the aspect and abilities of managers dealing with increasing the performance of their subordinates, their relationships in the workplace, division of labour and the overall organization of the team regarding their emotions and individual feeling of importance in the work process.

Purpose of the article: The aim of the survey was to find out how today's managers behave in common situations that occur in the daily work of managers. It was also investigated to what extent managers use emotional intelligence and whether they are emotionally stable enough to work as a manager.

Methods: A questionnaire survey was attended by managers. The questionnaire contained two parts. Firstly, the filtering questions and secondly, the specific situations in managerial life were analyzed, from which the level of emotional intelligence of the given manager was evaluated.

Findings \& Value added: These results in the work served to suggest improving awareness and the importance of emotional intelligence in work environments. The knowledge gained from the questionnaire will help in possible further research to create similar activities and improvements to imply emotional intelligence in more efficient operation of the company. A manager with high emotional intelligence can communicate effectively with others, can tolerate, solve problems, and build relationships with and between his employees.
\end{abstract}

Keywords: emotional intelligence; management; organization, working environment; employment, performance

JEL Classification: $M 54 ; M 12 ; P 47$

\footnotetext{
* Corresponding author: vladimira.binasova@,fstroj.uniza.sk
} 


\section{Introduction}

Success in today's international climate - a far cry from only a decade ago - demands highly specialized yet closely linked groups of global business managers, country or regional managers, and worldwide functional managers. This kind of organization characterizes a transnational rather than an old-line multinational, international, or global company. In fact, in the volatile world of transnational corporations, there is no such thing as a universal global manager. (Araujo et al., 2018)

Emotional intelligence is the ability to understand and control one's own emotions and the emotions of others. The extent to which individuals maintain their abilities and skills in a particular social environment depends on that ability. It includes things like understanding how a person feels, the ability to empathize with others, and the ability to process emotions to improve the quality of life. (Bar-On, 2006), (Bartlett and Ghoshal, 2003), (Bubenik, 2004), (Bučková, Gašo and Pekarčíková, 2020),(Frandsen and Morsing, 2021).

Unlike IQ, we can say that EQ is one of the foundations of human success and satisfaction. In addition to the abilities intended for IQ (thinking, testing, decision-making based on logic), we also need those that fall under emotional intelligence for the normal and specific functioning of the personality. The structure of the quality of emotional intelligence includes competencies related to each other and competencies in the field of interpersonal relationships.

The success of all organizations depends mainly on the intelligence of each employee. (Frandsen and Morsing, 2021).

Yukl, (2002) understands management as an interactive process between managers and subordinates, in which managers try to influence the behavior of their employees in achieving the goals of the organization. In other words, managers motivate people to achieve a certain performance and use different methods to manage performance.

According to Bar-On, (2006), emotional intelligence is a set of emotional and social abilities and skills that can help people cope with the needs of everyday life and help them achieve greater efficiency in personal and social life.

From the available information in psychology and management literature on performance motivation, we know that there is currently no fully validated concept of performance motivation that could be widely used in a variety of settings. (Hitt et. al., 2020), (Kraft, 2019). (Lavelle et. al., 2021). (Liu and Maitlis, 2014), (Ližbetinová et. al., 2020), (Lomas, 2019). (Lundin et. al., 2021), Marescaux, De Winne and Brebels, 2021).

Performance motivation is considered to be a personally typical, relatively constant tendency of a person to achieve the best possible performance, or at least to stick to the best in activities in which it is possible to measure quality, and which may or may not succeed, resp. in which people can achieve successes or failures.

From a simplified point of view, if we look at a person in terms of his IQ, emotional quotient and ability of WQ (will quotient) as key character traits, then we get a young person and his image of readiness to succeed. A manager with high emotional intelligence can communicate effectively with others (Matsuo, 2018), (Matys, et al., 2020), can tolerate and manage change well, solve problems and build relationships with and between his employees Mičieta, et al. 2020). He can motivate them to work without management pressure. Nedeliakova, et. al. 2020), (Oreopoulos and Petronijevic, 2018), Oreopoulos et. al., 2019). Most of them have to have an open discussion with their superior and see him as a partner rather than a commander. (Shaffer et. al., 2016), (Stoermer et. al., 2021). (Vavrik et. al., 2017), (Więcek et. al., 2020).

Emotional intelligence is the capacity to understand and manage emotions. (Yukl, 2002). The skills involved in emotional intelligence are self-awareness, self-regulation, motivation, empathy, and social skills. 


\section{Methods}

The aim of the questionnaire was to find out how today's managers behave in common situations that occur in the daily work of managers. We also found out to what extent they use EI and whether they are emotionally stable enough to work as a manager.

We used a questionnaire as a research method and, due to Covid-19, it was sent only in electronic form via e-mail and social networks. The questionnaire was sent to companies based in the Slovak Republic, more specifically in the north of Slovakia. The results of the questionnaire were continuously shown to us on the page on which we created the questionnaire, so the collected data are easy to process and very clear.

The questionnaire contained two parts. First were filtering questions in which adepts entered basic information such as age, education, gender, position, and the like. In the next part, we asked about specific situations in everyday managerial life, from which we can evaluate at what level the emotional intelligence of a given manager is and whether we can say what an important aspect of EI is in the manager's work.

\section{Results}

The questionnaire survey showed that emotional intelligence is very important at work. The survey took place specifically from 16 March 2021 to 17 April 2021. The questionnaire was sent to 92 people, of whom 46 responses were returned. So exactly $50 \%$ of people completed the questionnaire. There are only a part of graphical results (Fig. 1, Fig. 2), because of limited paper length.

It can be seen in Figure 1 that $39.1 \%$ of respondents have repeatedly failed to control their feelings and emotions. Another $34.8 \%$ of respondents got out of control only once and $26.1 \%$ have never been able to control their feelings.

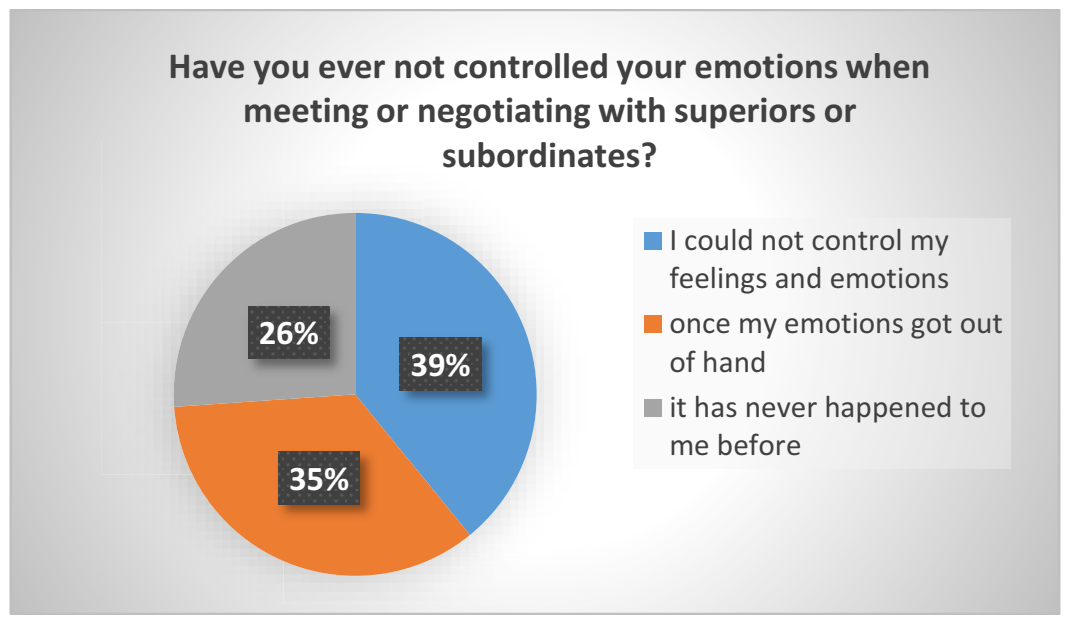

Figure 1. The ability to control emotions.

Source: Own Processing.

It follows from this question that $56.5 \%$ of managers can sympathize with others. $30.4 \%$ cannot describe their feelings towards others. $13 \%$ cannot sympathize with others. 


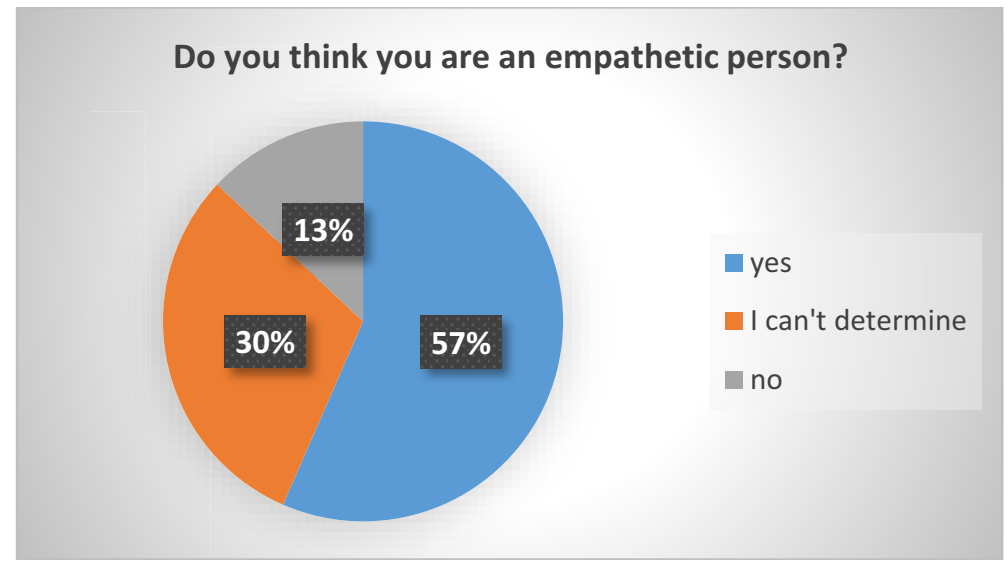

Figure. 2. Empathic of person.

Source: Own Processing.

As many as $95.7 \%$ agreed with this statement. In our opinion, the remaining $4.3 \%$ should reconsider their function in the work of a manager, because without emotional intelligence, no manager should function.

Most managers try to work with their subordinates in a friendly manner, regardless of their senior position. $17.4 \%$ of managers do not care so much about a friendly atmosphere.

In another question, he examined the influence of emotional intelligence on the work of a manager.

Fig. 3 shows that $43.5 \%$ of managers think that EI has an impact on success. $21.7 \%$ of respondents are convinced of this. $17.4 \%$ of respondents could not answer and $17.4 \%$ respondents think that EI has no effect on the success of the manager.

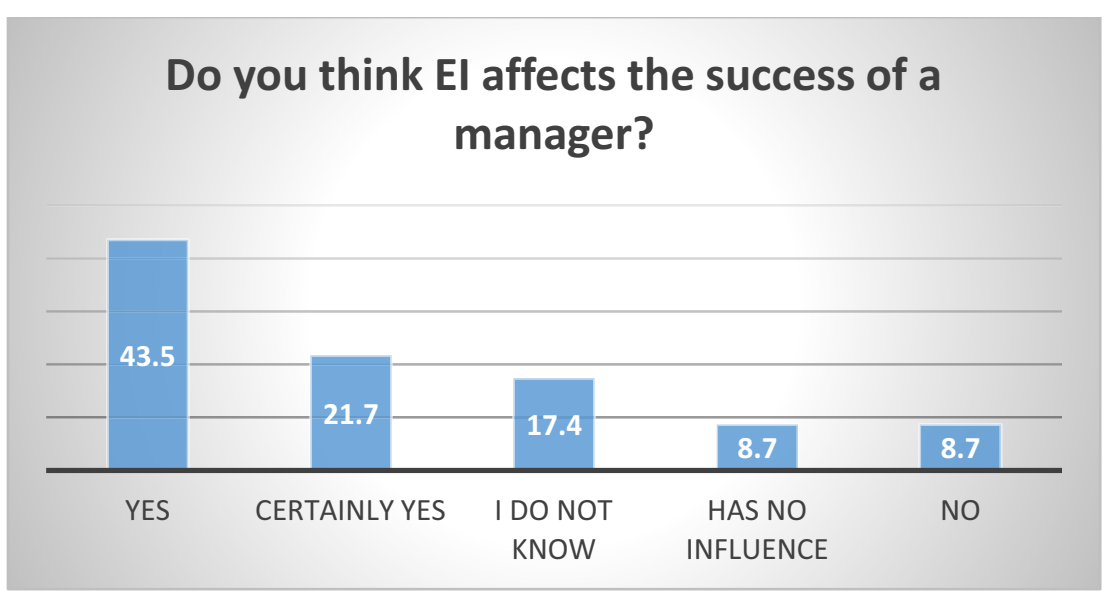

Figure. 3. EI and impact on the success of a manager.

Source: Own Processing.

\section{Discussions}

Research on emotion psychology suggests that people with high EQs also have strong social skills. Because they are adept at recognizing other people's emotions, they are able to respond 
appropriately to the situation. Social skills are also highly valued in the workplace because they lead to better communication and a more positive company culture.

The first filtering questions showed that for the most part the managerial function is occupied by men and their age is relatively low, which gives companies more opportunities to involve dynamic and modern elements in their activities. An interesting finding was that the completed education at the university level is not a condition for the management of the company, as the qualities needed to perform this function can be obtained in another environment.

Respondents were represented in all types of management, which contributes to the relevance of the whole questionnaire, it was also answered by managers with different time activities in their profession.

The gratifying fact was that manager answering the questions of the questionnaire are aware of the existence of the concept of emotional intelligence and most of them can use it, but positive answers did not reach one hundred percent, so some training and activities encouraging managers to differentiate employees are involved in their process. improvement. It turned out that most managers are satisfied with their lives, which may indicate that the position of manager suits them and fulfills them internally, as well as that they can transfer this life satisfaction to the team at work. It is right that they have the ability to separate their personal lives from working life, but there may be a situation in which they will have to make an excessive effort to control their emotions, so it is advisable to prepare for such moments. Preventing problems in the company is as important as solving them. The manager is also only a human being and it is natural that his feelings will manifest, but he must know how to prevent the negative influences resulting from such experiences from affecting the operation of the company. Therefore, the following section will focus on possible activities to improve the use of emotional intelligence in the work of managers.

\section{Conclusions}

The knowledge gained from the questionnaire will help in possible further research to create similar activities and improvements to imply emotional intelligence in the smooth and more efficient operation of the company. One of the main factors in such an activity is to know not only yourself, but also the other party, i.e. not only the manager, but also everyone to whom this process needs to be applied. Therefore, it is necessary to be interested in the feelings of its employees. The most appropriate way to find out their perception would be a whiteboard with a writing tool on which employees could write constructive criticism of the company's management, their ideas for improvement, praise and suggestions for increasing efficiency. In this way, a sense of importance will be created in them and the employer and the whole team of managers will have a better overview of the work team.

Another possible improvement would be the provision of benefits to employees in the form of remuneration, whether regular, i.e. monthly or annual or task-based. They could receive rewards for well-done work, motivational financial rewards or non-financial in the form of a product. Employees would feel valued and would be more motivated to do their job.

Stress is exceptionally not part of the job, so it is necessary to eliminate it as much as possible. Simple anti-stress aids could be used to make this more effective, such as available armchairs with cushions in company premises, coloring books, strengthening springs or rubber balls. The mentioned funds are not demanding for maintenance and do not significantly burden the company's financial budget. Simple objects could be used to break down this natural human emotion and would not have a negative effect on the work process.

Ideally, to make the working atmosphere more pleasant, it would be appropriate to set aside a whole room with game consoles, coffee machines or sweets with a certain employee 
discount and spaces for closer socialization, which would benefit the building of interpersonal relationships in the workplace.

\section{Acknowledgements}

This work was supported by the Slovak Research and Development Agency under the contract No. APVV-19-0305.

\section{References}

1. Araujo, M. C., Carneiro, P., Cruz-Aguayo, Y., \& Schady, N. (2016). Teacher quality and learning outcomes in kindergarten. The Quarterly Journal of Economics, 131(3), 14151453.

2. Bar-On, R. (2006). The Bar-On Model of Emotional -Social Inteligence (ESI). Psicothema, 18, 13-25.

3. Bartlett, C. A., \& Ghoshal, S. (2003). What is a global manager? Harvard business review, 81(8), 101-108.

4. Bubenik, P. (2004). Scheduling system for minimizing the costs of production. Journal of mechanical engineering, 50(5), 291-297.

5. Bučková, M., Gašo, M., \& Pekarčíková, M. (2020). Reverse logistic InvEnt 2020: Industrial engineering - Invention for enterprise. 1. vyd. Bielsko-Biała: Wydawnictwo Akademii Techniczno-Humnistycznej.

6. Frandsen, S., \& Morsing, M. (2021). Behind the stigma shield: Frontline employees' emotional response to organizational event stigma at work and at home. Journal of Management Studies, Early access.

7. Hitt, M. A., Arregle, J. L., \& Holmes Jr, R. M. (2020). Strategic management theory in a post-pandemic and non-ergodic world. Journal of Management Studies, 51(1), 257262.

8. Kraft, M. A. (2019). Teacher effects on complex cognitive skills and social-emotional competencies. Journal of Human Resources, 54(1), 1-36.

9. Lavelle, J. J., Rupp, D. E., Herda, D. N., Pandey, A., \& Lauck, J. R. (2021). Customer injustice and employee performance: roles of emotional exhaustion, surface acting, and emotional demands-abilities fit. Journal of Management, 47(3), 654-682.

10. Liu, F., \& Maitlis, S. (2014). Emotional dynamics and strategizing processes: A study of strategic conversations in top team meetings. Journal of Management Studies, 51(2), 202-234.

11. Ližbetinová, L., Hitka, M., Soušek, R., \& Caha, Z. (2020). Motivational preferences within job positions are different: empirical study from the Czech transport and logistics enterprises. Economic Research-Ekonomska Istraživanja, 1-21.

12. Lomas, T. (2019). Positive work: a multidimensional overview and analysis of workrelated drivers of wellbeing. International Journal of Applied Positive Psychology, 3(1), 69-96.

13. Lundin, M., Skans, O. N., \& Zetterberg, P. (2021). Leadership experiences, labor market entry, and early career trajectories. Journal of Human Resources, 56(2), 480-511.

14. Marescaux, E., De Winne, S., \& Brebels, L. (2021). Putting the Pieces Together: A Review of HR Differentiation Literature and a Multilevel Model. Journal of Management, 47(6), 1564-1595. 
15. Matsuo, M. (2018). How does managerial coaching affect individual learning? The mediating roles of team and individual reflexivity. Personnel review.

16. Matys, M., Krajčovič, M., Gabajová, G., Furmannnová, B., \& Burganová, N. (2020). Methodology of reating a virtual environment using the unity $3 \mathrm{D}$ game engine. In $\mathrm{P}$. Trebuna, M. Kliment, J. Trojan, \& M. Mizerák (Eds.), TIABP 2020. Proceedings of the XXIII. International Scientific Conference, Slovakia, Vol. 23. (pp. 120-127).

17. Mičieta, B., Biňasová, V., Kasajová M., Gabajová, G., \& Furmannová, B. (2020). The Use of a Six-Level Model of Business Development in Practice. In T. Kliestik (Eds.), The 20th International Scientific Conference Globalization and its Socio-Economic Consequences, Slovakia, 08014.

18. Nedeliakova, E., Hudakova, M., Masar, M., Lizbetinova, L., Stasiak-Betlejewska, R., \& Sulko, P. (2020). Sustainability of railway undertaking services with lean philosophy in risk management - Case study. Sustainability, 12(13), 5298.

19. Oreopoulos, P., \& Petronijevic, U. (2018). Student coaching: How far can technology go?. Journal of Human Resources, 53(2), 299-329.

20. Oreopoulos, P., Patterson, R. W., Petronijevic, U., \& Pope, N. G. (2019). Low-touch attempts to improve time management among traditional and online college students. Journal of Human Resources, 0919-10426R1.

21. Shaffer, M. A., Reiche, B. S., Dimitrova, M., Lazarova, M., Chen, S., Westman, M., \& Wurtz, O. (2016). Work-and family-role adjustment of different types of global professionals: Scale development and validation. Journal of International Business Studies, 47(2), 113-139.

22. Stoermer, S., Davies, S., \& Froese, F. J. (2021). The influence of expatriate cultural intelligence on organizational embeddedness and knowledge sharing: The moderating effects of host country context. Journal of International Business Studies, 52(3), 432453.

23. Vavrik V., Gregor M., \& Grznar P. (2017). Computer simulation as a tool for the optimization of logistics using automated guided vehicles. Procedia Engineering, 192, 923-928.

24. Więcek, D., Więcek, D., \& Dulina, L. (2020). Materials requirement planning with the use of activity based costing. Management systems in production engineering, 28(1), 38

25. Yukl, G, A. (2002). Leadership in Organizations. Prentice Hall: National College for School Leadership. 